\title{
Alcohol Sales
}

\section{and Socioeconomic Factors}

\section{Related to}

\section{Cirrhosis of the Liver Mortality}

in Pennsylvania

B ECAUSE cirrhosis of the liver is frequently associated with a history of chronic alcoholism, we decided to investigate the relationship between cirrhosis of the liver mortality and the per capita consumption of alcohol. Certain socioeconomic characteristics were taken into consideration.

\section{Background}

The term cirrhosis is derived from the Greek word kirrhos meaning yellow. This term, however, is a misnomer in that not all cirrhotic livers are yel-

Dr. Tokuhata is division director, Mr. Digon is chief, biostatistical research, and Mr. Ramaswamy is a biostatistician, division of research and biostatistics, Pennsylvania Department of Health. Dr. Tokuhata is also associate professor, community medicine, Temple University School of Medicine, and associate professor, biostatistics, University of Pittsburgh Graduate School of Public Health. Tearsheet requests to Dr. George K. Tokuhata, Pennsylvania Department of Health, P.O. Box 90, Harrisburg, Pa. 17120.
GEORGE K. TOKUHATA, Dr.P.H., Ph.D. EDWARD DIGON, M.P.H.

KRISHNAN RAMASWAMY, M.Sc., M.S.(Hy:

low. Girrhosis of the liver, according to Mallory (1), may be diagnosed when the following morphological evidence is present; destruction of liver cells by either acute episode or chronic progressive process, real or apparent increase in connective tissue, increased consistence of the liver, granularity or nodularity of the surface and on section, and hypertrophy during early stages and hypotrophy in later stages.

The exact pathogenesis of cirrhosis of the liver is not presently known. The disease may be classified either by etiology or by morphological characteristics, or both. Although viral hepatitis, hemochromatosis, obstruction and infection of the biliary tree, or both, or other factors can cause the disease, probably fatty nutritional cirrhosis is the most common. This type is often associated with chronic alcoholism in which inadequate diets and poor nutritional status are frequently juxtaposed.

Because of these observations, many attempts have been made experimentally to induce cirrhosis of the liver in animals by giving them various alcoholic beverages. The results of such experiments, 
however, have been generally unsuccessful, which have led some investigators to believe that alcohol may be a promoting agent, whereas dietary insufficiency may be an initiating factor. Chronic nutritional deficiency can result in severe fatty infiltration of the liver. Specifically, the most important cause of such fatty degeneration is considered to be a lack of lipotropic substances, such as choline, methionine, and riboflavin in the diet.

Daft (2) has demonstrated that choline and methionine prevent both cirrhosis and hemorrhagic necrosis of the liver in rats. Connor (3) has also shown convincingly that cirrhosis can be induced in dogs by giving them alcohol after fatty liver had been developed by dietary measures. The possibility that dietary deficiencies, particularly protein and lipotropic factors, potentiate the hepatotoxic effect of alcohol has been further evaluated in rats by Klatskin and co-workers (4) and by Lieber and co-workers (5). In contrast, certain scientists (6) contend that nutritional deficiency plays a limited role in the pathogenesis of liver disease.

Proponents of the thesis that diet is the major determinant in the fatty liver observed in alcoholics emphasize the role of calories from alcohol in creating nutrient imbalance (7). Dietary imbalance seems to be a key factor since persons with total starvation do not develop fatty liver. The process of fatty degeneration can be reversed by a high protein intake. Hepatic steatosis may result from metabolic effects of alcohol, but recent studies suggest that alcohol-induced changes in absorption or utilization of ingested food are also important (8). Leevy and Baker (9) stated that many chronic alcoholics with overt stigmata of malnutrition exhibit normal liver structure and function; thus factors as yet undefined determine susceptibility of certain alcoholics to fatty liver. Other factors, such as diabetes, obesity, and Wilson's disease can also contribute.

Other investigators believe that an established disease of the liver may affect nutrition, including the protein metabolism (10). Still others maintain that the diet which lacks certain B complex vitamins increases voluntary alcohol intake; thus nutritional factors can alter the appetite for alcohol (11). It seems unwise, then, to conclude that alcoholism is merely a cause of undernutrition.

Nevertheless, some persons, because of their genetic makeup, require more of certain nutrients than they are likely to get from ordinary food; for this reason they tend to become deficient in such elements. Williams (12) has suggested that inborn metabolic abnormalities render certain persons incapable of utilizing the foodstuffs in their diet before they become alcoholics.

\section{Problems}

Recently there has been increasing awareness of the problems associated with cirrhosis of the liver in the United States and elsewhere. No reliable data, however, are currently available as to the prevalence of this condition in the general population, nor have there been sufficient studies to determine the etiology of this disease or to explain the recent trend in the rising mortality attributed to this cause.

A review of epidemiologic literature showed some conflicting opinions regarding the etiology of cirrhosis of the liver. Much of such confusion would seem to be related to the methodological problems experienced by different investigators. For example, the results of many statistical studies were not compatible because of differences in some of the basic biological characteristics of study populations, such as race, sex, and age composition. There have been few, if any, adequate control data on human beings. Alsa, there still exists a certain ambiguity in the definition and classification of the disease which, in turn, affects clinical evaluation of hospital patients as well as pathological interpretation of tissues from autopsies.

On the basis of available clinical data and of extensive experimental studies, Jolliffe and Jellinek (13) concluded in 1942 that there was a direct association between consumption of alcohol and cirrhosis of the liver. This view was challenged in 1950 by Lilienfeld and Korn (14) on the ground that the existing evidence was not sufficient to support such a definite cause-and-effect relationship. they maintained, rather, that the association between alcoholism and cirrhosis might be of an indirect nature, and that certain other factors, such as industrial hazards, metabolic and nutritional abnormalities, and fatty degeneration might play a role in the pathogenesis of this disease. In 1967 Terris (15) provided further statistical evidence to support the view expressed earlier by Jolliffe and Jellinek (13), stating that per capita consumption of alcohol was directly related to the number of persons having cirrhosis of the liver. Terris' supporting evidence was based on the exceptionally high death rates from cirrhosis for occupational groups with the expected maximum exposure to 
alcohol, such as bartenders, waiters, and other entertainment or service personnel, and on the existing international differences in both the death rate from cirrhosis and the apparent per capita consumption of alcohol.

\section{Objective}

The major abjective of this study was to analyze cirrhosis mortality data pertaining to Pennsylvania in reference to some of the epidemiologic views expressed, particularly by Jolliffe and Jellinek, Lilienfeld and Korn, and Terris (13-15). Our data relate the actual per capita sale of alcohol by county to the mortality statistics on cirrhosis as well as to certain socioeconomic groupings of the State population. In addition, we compared median age at death of persons whose death certificates mentioned alcoholism with that of persons whose certificates lacked mention of alcoholism. We also computed the conditional probability by age group of a person dying from cirrhosis or from some other competing risk.

\section{Method}

Data on cirrhosis of the liver mortality were analyzed both historically and cross sectionally for the Commonwealth of Pennsylvania, and death certificates filed in the State health department were reviewed. For the purpose of our study, the diagnosis given in death certificates was accepted. Data regarding sale of alcohol by county were obtained from the 1960 annual report of the Pennsylvania State Liquor Control Board in which all alcoholic beverages except beer were considered. Other data such as family income, education, and percentage of urbanization were taken or computed from the report of the 1960 U.S. Census (16).

For most analyses, death rates were adjusted simultaneously for both age and sex by the direct method of standardization (17). Per capita sale of alcohol was computed using the adult population (21 years and over) of each county. Socioeconomic grouping of counties in Pennsylvania was derived from the six ranks originally established by the State Planning Board (18) and was based on a sevenfactor composite index. The seven factors used were population, housing, manufacturing, agriculture, mining, employment, and number of miles and size of highways.

\section{Results}

The death rate per 100,000 population from cirrhosis of the liver increased from 9.6 in 1940 to
14.8 in 1967 (table 1). Some of this increase was accounted for by the aging population of the State. A slight decrease in the rate for 1949 was a reflection of changes between the fifth and sixth revision of the International Classification of Diseases (ICD) ; the seventh revision of the ICD had a slight upward effect for the 1958 mortality rate for cirrhosis of the liver.

On the basis of the age-adjusted rate, since 1950 the relative quinquennial rise in the death rate became increasingly greater, although practically all of these increases were for males as compared with females. The rate for whites increased slowly but consistently during the entire 1950-65 period whereas the rate for nonwhites declined during the first 5 years of the same period and then rose rather rapidly and consistently during the remaining period (table 2). As of 1965 the adjusted mortality rate was 18.3 per 100,000 for males and 7.5 for females with only a slight predilection in nonwhites (13.6) as compared with whites (12.4).

Also included in table 2 are temporal statistics pertaining to the per capita sale of alcohol and the Consumer Price Index (CPI) for the same 4 years. As indicated by the price index, there was gradual inflation during the period analyzed. The net increase in the per capita sale of alcohol was estimated to be about 17 percent ( 38.7 percent minus 22.2 percent) during the $1950-60$ period and 27 percent (57.6 percent minus 30.4 percent) during the $1950-65$ period. During the $1950-60$ period, the death rate from cirrhosis of the liver in Pennsylvania increased by 5.4 percent and during the 1950-65 period, by 12.6 percent. It should be noted that the amount of increase in the per capita sale of alcohol

Table 1. Cirrhosis of liver deaths, number and crude rate per 100,000, Pennsylvania, 1940-67

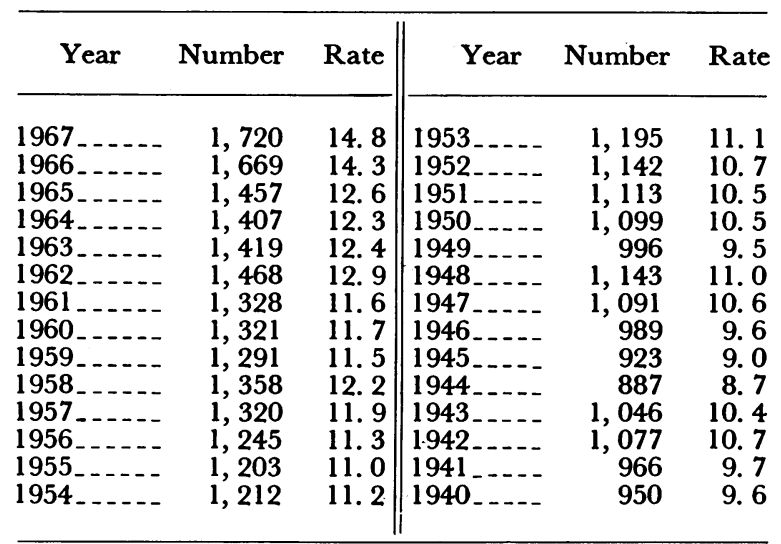


was much greater for the $1955-60$ period than for the 1950-55 period. This difference compares interestingly with a similar, but 5-year delayed, difference in the death rate from cirrhosis.

The 1960 mortality data were used for detailed cross-sectional analyses, because accurate census data were available. The median age of persons dying of cirrhosis of the liver for 1960 (table 3) was 59.3 years in Pennsylvania. This age compares unfavorably with the median age at death from all causes (69.7) for the same year. Among whites there was no particular difference by sex, but nonwhite women died of this disease at much younger ages (48.8 years) than did nonwhite men (53.3 years). The median age at death was 8.5 years greater for whites as a whole ( 59.9 years) than for nonwhites as a whole (51.4 years); this racial difference was much more clearly indicated in women than in men.

A marked difference in the median age at death was shown between persons whose death certificates mentioned alcoholism and those that did not. The result of this analysis is also summarized in table 3 . Those with alcoholism died much younger (55.3 years) as compared with those without alcoholism (61.0 years). Among the persons with alcoholism mentioned, the median age at death was considerably greater for men ( 56.7 years) than for women (51.8 years) - a trend which is contrary to the usual expectation. This unusual difference between sexes was indicated equally for both racial groups. In contrast, among the persons whose death certificates did not mention alcoholism such age was generally but slightly higher for women (62.2 years) than for men (60.3 years); a difference which was reversed when nonwhites were considered separately. It was particularly noteworthy that the median age at death was as low as 45.8 years for nonwhite women who were alcoholics and 51.3 years for nonwhite women who were not stated as being alcoholics. Nonwhites in Pennsylvania in this study were predominantly Negro, and the median ages

Table 2. U.S. Consumer Price Index, adult per capita sale of alcohol, and cirrhosis of liver death rates adjusted for age, Pennsylvania, 1950, 1955, 1960, and 1965

\begin{tabular}{|c|c|c|c|c|c|c|c|c|c|c|}
\hline Year & $\begin{array}{c}\text { U.S. } \\
\text { Consumer } \\
\text { Price } \\
\text { Index }\end{array}$ & $\begin{array}{c}\text { Percent } \\
\text { increase } \\
\text { in index } \\
\text { since } 1950\end{array}$ & $\begin{array}{l}\text { Adult } 1 \\
\text { per capita } \\
\text { alcohol } \\
\text { sales }\end{array}$ & $\begin{array}{c}\text { Percent } \\
\text { increase } \\
\text { in sales } \\
\text { since } 1950\end{array}$ & $\begin{array}{c}\text { Cirrhosis } \\
\text { deaths } \\
\text { per } \\
100,000\end{array}$ & $\begin{array}{c}\text { Percent } \\
\text { increase } \\
\text { in deaths } \\
\text { since } 1950\end{array}$ & $\begin{array}{c}\text { Male } \\
\text { deaths }\end{array}$ & $\underset{\text { deaths }}{\text { Female }}$ & $\begin{array}{l}\text { White } \\
\text { deaths }\end{array}$ & $\begin{array}{l}\text { Nonwhite } \\
\text { deaths }\end{array}$ \\
\hline $\begin{array}{l}1965 \ldots \\
1960 \ldots \\
1955 \ldots \\
1950 \ldots\end{array}$ & $\begin{array}{r}109.7 \\
103.0 \\
93.4 \\
84.3\end{array}$ & $\begin{array}{r}30.4 \\
22.2 \\
10.8\end{array}$ & $\begin{array}{r}\$ 47.96 \\
42.22 \\
32.70 \\
30.44\end{array}$ & $\begin{array}{r}57.6 \\
38.7 \\
7.4 \\
\end{array}$ & $\begin{array}{l}12.5 \\
11.7 \\
11.3 \\
11.1\end{array}$ & $\begin{array}{r}12.6 \\
5.4 \\
1.8 \\
-\end{array}$ & $\begin{array}{l}18.3 \\
17.2 \\
16.1 \\
14.9\end{array}$ & $\begin{array}{l}7.5 \\
6.8 \\
7.0 \\
7.5\end{array}$ & $\begin{array}{l}12.4 \\
11.8 \\
11.4 \\
10.9\end{array}$ & $\begin{array}{r}13.6 \\
9.7 \\
8.6 \\
14.4\end{array}$ \\
\hline
\end{tabular}

1 Persons 21 years or over.

Notes: Direct method of standardization was used (reference 17). 1960 State population figures were used as the base for computing all rates-male, female, white, and nonwhite. U.S. Consumer Price Indexes were used for this analysis because the 1965 Pennsylvania consumer price index was not available. It should be noted, however, that indexes of 84.8 for $1950,93.6$ for 1955 , and 103.5 for 1960 for Pennsylvania were comparable to those of the rest of the United States as a whole.

Table 3. Median age at death of persons whose deaths were attributed to cirrhosis, with or without mention of alcoholism on certificate, by sex and race, Pennsylvania, 1960

\begin{tabular}{|c|c|c|c|c|c|c|}
\hline \multirow{2}{*}{ Race and alcoholism } & \multicolumn{2}{|c|}{ Both sexes } & \multicolumn{2}{|c|}{ Male } & \multicolumn{2}{|c|}{ Female } \\
\hline & $\begin{array}{c}\text { Median age } \\
\text { (years) }\end{array}$ & $\begin{array}{c}\text { Number of } \\
\text { deaths }\end{array}$ & $\begin{array}{c}\text { Median age } \\
\text { (years) }\end{array}$ & $\begin{array}{l}\text { Number of } \\
\text { deaths }\end{array}$ & $\underset{\text { (years) }}{\text { Median age }}$ & $\begin{array}{c}\text { Number of } \\
\text { deaths }\end{array}$ \\
\hline \multicolumn{7}{|l|}{ With or without mention: } \\
\hline All races. & 59.3 & 1,320 & 59.3 & 920 & 59.2 & 400 \\
\hline White & 59.9 & 1,210 & 59.8 & 840 & 60.0 & 370 \\
\hline Nonwhite & 51.4 & 110 & 53. 3 & 80 & 48.8 & 30 \\
\hline \multicolumn{7}{|l|}{ With mention: } \\
\hline All races & 55.3 & 362 & 56.7 & 279 & 51.8 & 83 \\
\hline White & 56.2 & 332 & 57.3 & 262 & 52.7 & 70 \\
\hline Nonwhite & 48.3 & 30 & 50.6 & 17 & 45.8 & 13 \\
\hline \multirow{4}{*}{$\begin{array}{l}\text { Without mention: } \\
\text { All races } \\
\text { White } \\
\text { Nonwhite. }\end{array}$} & & & & & & \\
\hline & 61.0 & 958 & 60.3 & 641 & 62.2 & 317 \\
\hline & 61.5 & 878 & 61.0 & 578 & 62.7 & 300 \\
\hline & 53.6 & 80 & 55.6 & 63 & 51.3 & 17 \\
\hline
\end{tabular}




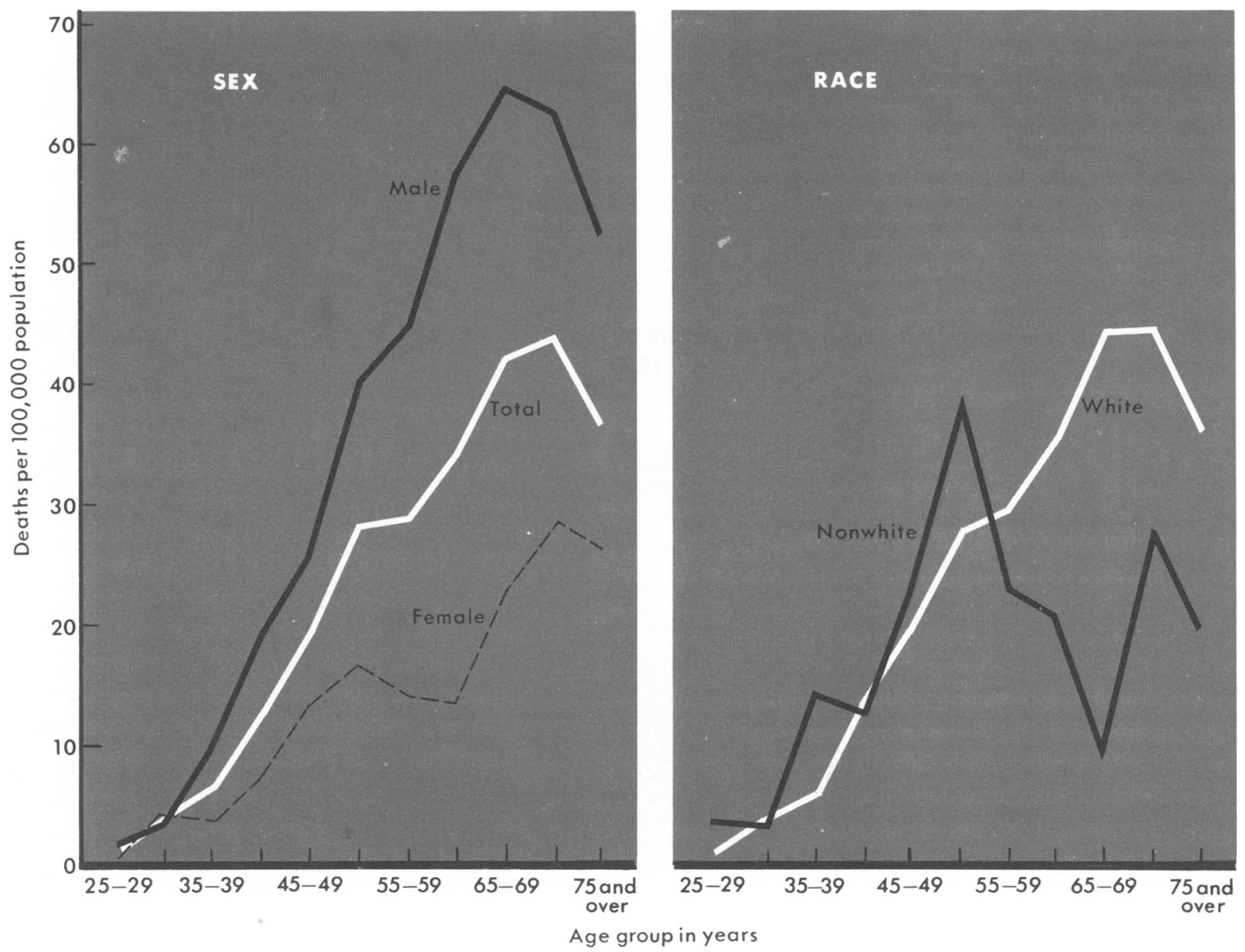

for these nonwhite women were based on relatively small numbers of deaths.

The median age at death among the white persons with cirrhosis with mention of alcoholism on the death certificate was only 56.2 years as compared with the expected 70.4 years, a difference of as much as 14.2 years; whereas for the nonwhite person, the median age was 48.3 years as compared with the expected 58.9 years, a difference of 10.6 years.

The age-specific death rates were computed for 1960 by race and sex, and the results are shown in table 4 . The death rate from cirrhosis was somewhat high in children under 15 years of age but did not reach significant levels until adult life. The rate in adults rose continuously with age until about 74 years but declined thereafter. The death rate of males did not predominate over that of females until after 35 years of age (fig. 1). Consistently higher rates for whites as compared with nonwhites were indicated at about 55 years of age (fig. 1).

In the presence of competing risks of death from other causes, a conditional probability was computed for each 5-year group, and then the percentage of risk contributed by cirrhosis was estimated (table 5 ). In children under 5 years, 1.5 percent of all risks of dying were attributed to cirrhosis of the liver. The relative contribution of this disease as the cause of death increased gradually to the highest level in the age group 25-29 years, in which as much as 11.3 percent of the total risks were accounted for, and then decreased consistently with age throughout the remaining periods of life. Beyond 75 years of age, cirrhosis of the liver virtually lost significance as the cause of death.

Three epidemiologic variables, using the county as a unit of observation, were considered for further analysis (table 6). Of the three variables, two were found to be significantly associated with the cirrhosis mortality rate. Specifically, the rate ad- 
justed for age and sex was positively correlated with the sale of alcohol per capita and the median family income. Of these two variables, the data on alcohol were much more strongly related to this disease regardless of whether or not alcoholism was mentioned in the death certificate. There was some relationship between the median education and the mortality rate, but this relationship was not statistically significant.

In a separate analysis, counties were divided into high, middle, and low socioeconomic groups ac- cording to the composite index (table 7). The death rate from cirrhosis varied slightly from the highest, 13 per 100,000 , in the low index group, to the lowest, 11 per 100,000 in the high index group. Within the low socioeconomic index group there was a remarkably high $(0.870)$ positive correlation between per capita sale of alcohol and the death rate from cirrhosis. The value of this productmoment correlation coefficient indicates that 76 percent of the total variation in the death rate is explainable by the alcohol factor. This was a

Table 4. Age-specific death rates from cirrhosis of the liver per 100,000 population, Pennsylvania, 1960

\begin{tabular}{|c|c|c|c|c|c|c|c|c|c|}
\hline \multirow{2}{*}{ Age group } & \multicolumn{3}{|c|}{ All races } & \multicolumn{3}{|c|}{ White } & \multicolumn{3}{|c|}{ Nonwhite } \\
\hline & $\begin{array}{l}\text { Both } \\
\text { sexes }\end{array}$ & Male & Female & $\begin{array}{l}\text { Both } \\
\text { sexes }\end{array}$ & Male & Female & $\begin{array}{l}\text { Both } \\
\text { sexes }\end{array}$ & Male & Female \\
\hline $\begin{array}{l}\text { Under } 15 \\
15-19 \\
20-24 \\
25-29 \\
30-34 \\
35-39 \\
40-44 \\
45049 \\
50-54 \\
60-594 \\
65-69 \\
70-74 \\
75 \text { and over }\end{array}$ & $\begin{array}{r}0.303 \\
.125 \\
.163 \\
.929 \\
3.517 \\
6.323 \\
12.860 \\
19.207 \\
28.108 \\
28.830 \\
34.278 \\
42.273 \\
43.927 \\
37.319\end{array}$ & $\begin{array}{r}0.239 \\
.255 \\
.350 \\
1.283 \\
3.239 \\
9.627 \\
19.084 \\
25.188 \\
40.314 \\
44.658 \\
57.595 \\
64.611 \\
62.548 \\
52.624\end{array}$ & $\begin{array}{r}0.371 \\
3.777 \\
3.274 \\
7.063 \\
13.493 \\
16.489 \\
13.973 \\
13.146 \\
22.676 \\
28.272 \\
26.079\end{array}$ & $\begin{array}{r}0.333 \\
.136 \\
.178 \\
.681 \\
3.553 \\
5.680 \\
12.879 \\
19.020 \\
27.445 \\
29.294 \\
35.195 \\
44.149 \\
44.668 \\
38.074\end{array}$ & $\begin{array}{r}0.261 \\
.276 \\
.382 \\
1.052 \\
3.225 \\
9.344 \\
19.634 \\
25.489 \\
40.057 \\
45.369 \\
60.639 \\
67.430 \\
63.486 \\
53.635\end{array}$ & $\begin{array}{r}0.408 \\
3.331 \\
2.282 \\
6.559 \\
12.809 \\
15.414 \\
14.263 \\
12.306 \\
23.866 \\
28.923 \\
26.644\end{array}$ & $\begin{array}{r}3.438 \\
\text { 3. } 123 \\
13.773 \\
12.610 \\
21.755 \\
37.575 \\
22.641 \\
20.067 \\
8.765 \\
27.847 \\
19.983\end{array}$ & $\begin{array}{r}3.769 \\
\text { 3. } 402 \\
12.967 \\
11.539 \\
20.932 \\
44.059 \\
35.445 \\
13.281 \\
17.576 \\
43.333 \\
29.841\end{array}$ & $\begin{array}{r}3.159 \\
2.886 \\
14.495 \\
13.554 \\
22.492 \\
31.595 \\
10.000 \\
26.952 \\
13.439 \\
12.032\end{array}$ \\
\hline All ages . . . . & 11.670 & 16. 624 & 6. 972 & 11.957 & 17. 216 & 6. 959 & 8. 205 & 9. 376 & 7. 121 \\
\hline
\end{tabular}

Note: Includes all deaths with or without alcoholism mentioned on death certificate. Subgroups without rates indicate no deaths attributed to this cause.

Table 5. Probability of dying from all causes, causes other than cirrhosis, from cirrhosis, and percentage of mortality risk from cirrhosis of the liver, by age group, Pennsylvania, 1960

\begin{tabular}{|c|c|c|c|c|}
\hline \multirow[b]{2}{*}{$\begin{array}{l}\text { Age interval (in years) } \\
\qquad X_{i} \text { to } X_{i}+_{i}\end{array}$} & \multicolumn{4}{|c|}{ Probability of dying from- } \\
\hline & $\begin{array}{l}\text { All causes } \\
\hat{q}_{i}\end{array}$ & $\begin{array}{c}\text { Causes other } \\
\text { than cirrhosis } \\
\hat{q}_{i \cdot 1}\end{array}$ & $\begin{array}{c}\text { Liver cirrhosis } \\
\text { in the presence } \\
\text { of other risks } \\
\hat{q}_{i-\hat{q}_{i \cdot 1}}\end{array}$ & $\begin{array}{c}\text { Percentage risk } \\
\text { contributed by } \\
\text { cirrhosis } \\
\frac{\hat{q}_{i-} \hat{q}_{i \cdot 1}}{\hat{q}_{i}} \times 100\end{array}$ \\
\hline $\begin{array}{l}0 \\
0\end{array}$ & $\begin{array}{l}0.0277 \\
.0022 \\
.0019 \\
.0034 \\
.0050 \\
.0052 \\
.0066 \\
.0109 \\
.0177 \\
.0298 \\
.0477 \\
.0720 \\
.1137 \\
.1633 \\
.2330 \\
.9817\end{array}$ & $\begin{array}{l}0.0273 \\
.0021 \\
.0018 \\
.0033 \\
.0046 \\
.0046 \\
.0060 \\
.0105 \\
.0169 \\
.0288 \\
.0463 \\
.0706 \\
.1121 \\
.1613 \\
.2312 \\
.9814\end{array}$ & $\begin{array}{r}0.0004 \\
.0001 \\
.0001 \\
.0001 \\
.0004 \\
.0006 \\
.0006 \\
.0004 \\
.0008 \\
.0010 \\
.0014 \\
.0014 \\
.0026 \\
.0020 \\
.0018 \\
.0003\end{array}$ & $\begin{array}{r}1.5 \\
4.4 \\
5.2 \\
3.0 \\
7.8 \\
11.3 \\
8.8 \\
4.1 \\
4.6 \\
3.3 \\
2.9 \\
2.0 \\
2.3 \\
1.2 \\
.8 \\
0.0\end{array}$ \\
\hline
\end{tabular}


Figure 2. Correlation between per capita alcohol sale and cirrhosis of the liver death rate per 100,000, by composite socioeconomic grouping, Pennsylvania, 1960
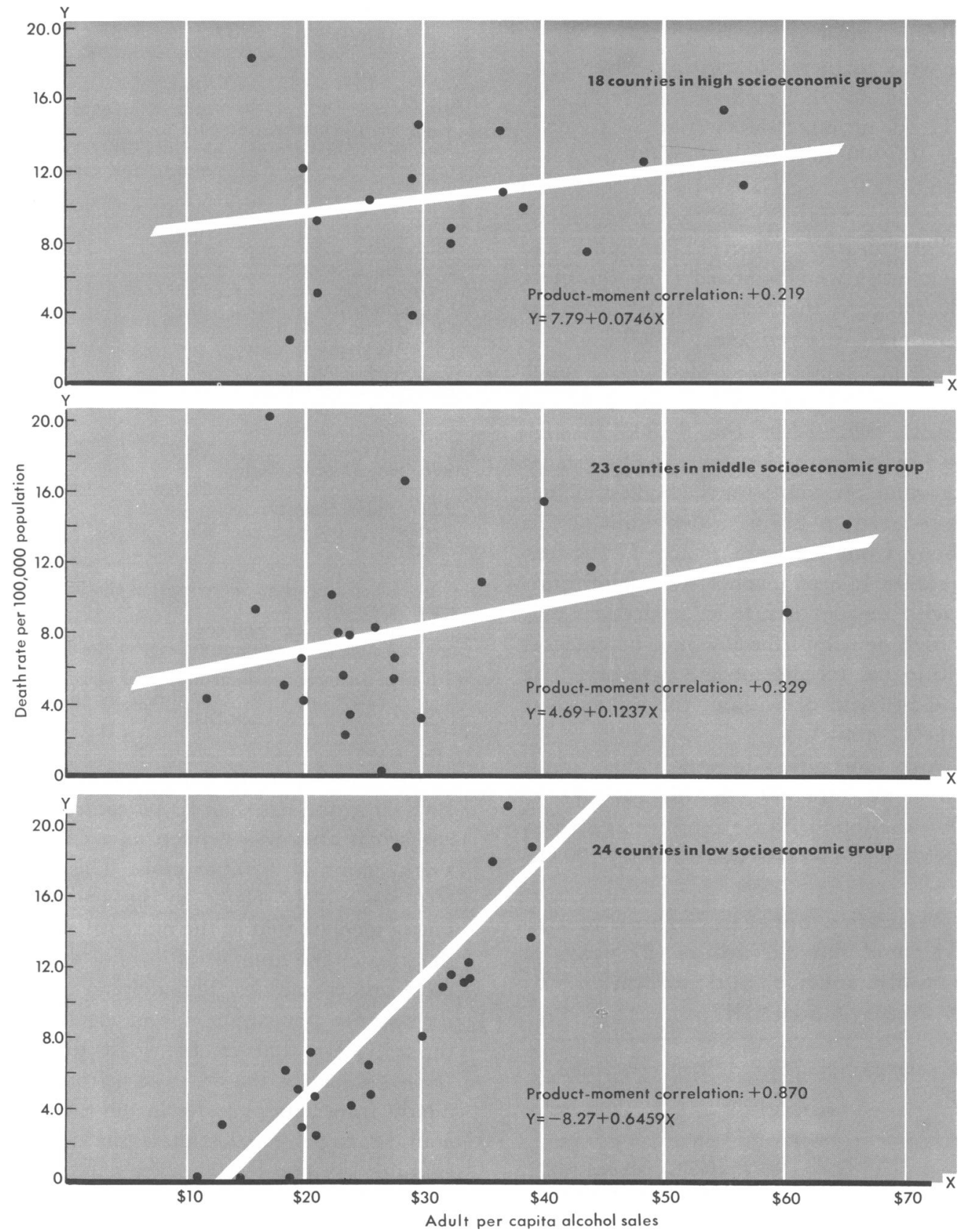

linear relationship with the computed equation $Y=-8.27+0.6459 X$. According to this equation, there seems to be a threshold value of the effect of alcohol consumption (approximately $\$ 13$ per adult per year as of 1960) on the cirrhosis mortality. In none of the other two index groups was there such a correlation found. This relationship is illustrated in figure 2.

The average per capita sale of alcohol was also computed for each of the high, middle, and low socioeconomic index groups. When Allegheny and Philadelphia Counties were removed from the remaining counties, the average per capita value was greatest for the high index group as compared with the middle and low index groups. The actual death rate for cirrhosis, however, was not different between the high and middle index groups. The rate was by far the greatest in the two most metro- 
politan counties, Philadelphia, 14.8 per 100,000, and Allegheny, 15.4 per 100,000, where per capita sale of alcohol was also the greatest- $\$ 65$ for Philadelphia and $\$ 55$ for Allegheny.

Counties were further grouped into three categories according to the median family income (table 8). The death rate from cirrhosis was equally high, 12 per 100,000 , in both the more than $\$ 5,600$ and less than $\$ 4,800$ categories and when compared with the nine per 100,000 of the intermediate $\$ 4,800-\$ 5,599$ category. When Philadelphia and Allegheny Counties were removed from the more than $\$ 5,600$ category, the death rate for liver cirrhosis was reduced to seven per 100,000 .

The average per capita sale of alcohol was much greater for the more than $\$ 5,600$ group, $\$ 48.77$ as compared with $\$ 28.69$ for the $\$ 4,800$ through $\$ 5,599$, and $\$ 28.09$ for the less than $\$ 4,800$ groups. The average value per capita for the highest income group was reduced to $\$ 37.62$ when Philadelphia and Allegheny Counties were removed. Furthermore, per capita sale of alcohol was significantly correlated with the death rate from cirrhosis only within the high or within the low income category but not within the middle income category. This correlation exists with or without the influence of the two largest counties.

The cirrhosis mortality rate was higher in the more urban areas (table 9); the highest rate, 13 per 100,000, was found in the more than 50 percent urban counties. The rate was eight per 100,000

\section{Table 6. Association between cirrhosis mortal- ity and alcohol sale for adults (21 years or older), family income and education, by counties, Pennsylvania, 1960}

\begin{tabular}{ccc}
$\begin{array}{c}\text { Variable of county's } \\
\text { population }\end{array}$ & $\begin{array}{c}\text { Number } \\
\text { of } \\
\text { counties }\end{array}$ & $\begin{array}{c}\text { Rank correlation } \\
\text { coefficient }\end{array}$ \\
\hline
\end{tabular}

\begin{tabular}{|c|c|c|}
\hline Per capita alcohol sale ${ }^{1}$ - & 65 & 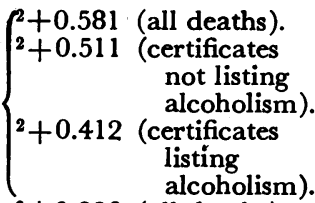 \\
\hline $\begin{array}{l}\text { Median family income } \\
\text { Median education }\end{array}$ & $\begin{array}{l}67 \\
67\end{array}$ & $\begin{array}{l}{ }^{2}+0.336 \text { (all deaths). } \\
+0.220 \text { (all deaths). }\end{array}$ \\
\hline
\end{tabular}

\footnotetext{
1 Based on population of those 21 years or older.

2 Statistically significant at least at the 1 percent level.

Note: Death rates adjusted for age and sex.
}

Source: For county per capita sales of alcohol-1960 annual report of the Pennsylvania Liquor Control Board. County median family income and education were from the 1960 U.S. Census.
Table 7. Cirrhosis of liver mortality rate by county socioeconomic grouping and correlation with the average per capita alcohol sale, Pennsylvania, 1960

\begin{tabular}{|c|c|c|c|}
\hline $\begin{array}{l}\text { Counties and composite } \\
\text { socioeconomic group }\end{array}$ & $\begin{array}{l}\text { Adult } \\
\text { per } \\
\text { capita } \\
\text { alcohol } \\
\text { sales } 1\end{array}$ & $\begin{array}{c}\text { Death } \\
\text { rate per } \\
100,000^{2} \\
\text { (all cases) }\end{array}$ & $\begin{array}{l}\text { Association } \\
\text { with per } \\
\text { capita } \\
\text { alcohol sale } \\
\text { (rank } \\
\text { correlation) }\end{array}$ \\
\hline
\end{tabular}

\begin{tabular}{|c|c|c|c|}
\hline $\begin{array}{l}18 \text { counties, high group- } \\
23 \text { counties, middle }\end{array}$ & $\$ 41.75$ & 11.1 & +0.181 \\
\hline $\begin{array}{l}\text { group } \\
24 \text { counties, low group.- } \\
17 \text { counties, excluding }\end{array}$ & $\begin{array}{l}49.09 \\
30.38\end{array}$ & $\begin{array}{l}11.9 \\
13.2\end{array}$ & $\begin{array}{r}+.283 \\
3+.880\end{array}$ \\
\hline $\begin{array}{l}\text { Allegheny County, } \\
\text { high group.--- } \\
22 \text { counties, excluding } \\
\text { Philadelphia }\end{array}$ & 36. 22 & 9.3 & .127 \\
\hline $\begin{array}{l}\text { County, middle } \\
\text { group } \\
\text { Allegheny County, high }\end{array}$ & 29. 93 & 8. 7 & +.213 \\
\hline group & 54.83 & 15.4 & \\
\hline $\begin{array}{l}\text { Philadelphia County, } \\
\text { middle group. }\end{array}$ & 65.21 & 14.8 & \\
\hline
\end{tabular}

1 Alcohol sale data were not available for Union and Forest Counties.

2 Adjusted for age and sex.

3 Statistically significant at least at the 1 percent level.

Note: Socioeconomic grouping of counties was based on the six ranks originally established by the State Planning Board in 1964 (reference 18).

in the 25-49 percent urban counties and six per 100,000 in the less than 25 percent urban counties. An urban area was defined as a community with a population of 2,500 or more. This mortality pattern was closely related to the average per capita sale of alcohol, that is, the more urbanized the area, the greater the amount of alcohol sold. In the two most urban counties, Philadelphia and Allegheny, the average per capita sale of alcohol was almost thrice $(\$ 60)$ that in the least urbanized areas $(\$ 21)$; similarly, the death rate from cirrhosis was almost three times greater in the two metropolitan counties, 15 per 100,000, than that in the least urban counties, six per 100,000 . Per capita sale by each county was correlated significantly with the death rate from cirrhosis only where the degree of urbanization was either high or low but not in the intermediate areas.

The death certificates from each county for persons dying from cirrhosis of the liver were further examined to compare the number of those with mention of alcoholism to the number without mention of alcoholism. The four counties-Armstrong, Fulton, Juniata, and Wyoming-reporting no deaths from cirrhosis of the liver were excluded 
Table 8. Cirrhosis of liver death rate per 100,000 and association with per capita sale of alcohol according to county median income grouping, Pennsylvania, 1960

\begin{tabular}{|c|c|c|c|}
\hline $\begin{array}{l}\text { Number of counties } \\
\text { and median family } \\
\text { income }\end{array}$ & $\begin{array}{l}\text { Adult } \\
\text { per } \\
\text { capita } \\
\text { alcohol } \\
\text { sales }\end{array}$ & $\begin{array}{c}\text { Death } \\
\text { rate } \\
\text { per } \\
100,000 \\
\text { (all cases) }\end{array}$ & $\begin{array}{l}\text { Association } \\
\text { with per } \\
\text { capita alco- } \\
\text { hol sale } \\
\text { (rank cor- } \\
\text { relation) }\end{array}$ \\
\hline 21 counties, more than & $\$ 48.77$ & 12.3 & $1+0.473$ \\
\hline $\begin{array}{l}19 \text { counties, excluding } \\
\text { Allegheny and Phil- } \\
\text { adelphia, more than } \\
\$ 5,600\end{array}$ & 37.62 & 7.4 & $1+.412$ \\
\hline $\begin{array}{l}24 \text { counties, } \$ 4,800 \\
\$ 5,599 \\
20 \text { counties, less than }\end{array}$ & 28. 69 & 9.3 & +.256 \\
\hline $\begin{array}{l}2 \text { counties, Allegheny } \\
\text { and Philadelphia, } \\
\text { more than } \$ 5,600\end{array}$ & 28. 09 & 12. 2 & ${ }^{2}+.691$ \\
\hline
\end{tabular}

${ }^{1}$ Statistically significant at least at the 5 percent level.

${ }^{2}$ Statistically significant at least at the 1 percent level.

NotE: Death rates were adjusted for age and sex.

from the analysis. In the following list, the counties are grouped within ranges of ratios, that is, the ratio of the number of certificates without mention of alcoholism to the certificates with mention of alcoholism. A ratio less than 1.00 indicates that alcoholism was mentioned more often than not; a higher ratio indicates that there were fewer certificates mentioning alcoholism than those not mentioning alcoholism.

\begin{tabular}{|c|c|}
\hline $\begin{array}{l}\text { Range of ratios } \\
\text { (without mention } \\
\text { to mention) }\end{array}$ & Counties \\
\hline Numerator $0_{-}$ & Bradford, Snyder, Wayne \\
\hline $0.10-0.99$ & Erie, Greene, Indiana, Jefferson \\
\hline $1.00-1.99$ & $\begin{array}{l}\text { Adams, Centre, Philadelphia, Wash- } \\
\text { ington, York }\end{array}$ \\
\hline $2.00-2.99$ & $\begin{array}{l}\text { Berks, Bucks, Butler, Fayette, Mc- } \\
\text { Kean, Monroe, Northampton, } \\
\text { Pike, Westmoreland }\end{array}$ \\
\hline $3.00-3.99$ & $\begin{array}{l}\text { Allegheny, Dauphin, Lycoming, } \\
\text { Montour }\end{array}$ \\
\hline $4.00-4.99$ & $\begin{array}{l}\text { Beaver, Cambria, Carbon, Lacka- } \\
\text { wana, Luzerne, Montgomery }\end{array}$ \\
\hline 5.00 or more & $\begin{array}{l}\text { Chester, Cumberland, Delaware, } \\
\text { Elk, Lancaster, Lawrence, Le- } \\
\text { high, Mercer, Northumberland, } \\
\text { Schuylkill, Somerset }\end{array}$ \\
\hline Denominator 0 & $\begin{array}{l}\text { Bedford, Blair, Cameron, Clarion, } \\
\text { Clearfield, Clinton, Columbia, } \\
\text { Crawford, Forest, Franklin, Hunt- } \\
\text { ingdon, Lebanon, Mifflin, Perry, } \\
\text { Potter, Sullivan, Susquehanna, } \\
\text { Tioga, Union, Venango, Warren }\end{array}$ \\
\hline
\end{tabular}

In seven (11 percent) of the 63 counties, there were more certificates with mention of alcoholism than there were without mention. In three of these seven counties, all persons who died of cirrhosis were identified as alcoholics. In contrast, in 21 (33 percent) of the 63 counties, all deaths attributed to cirrhosis were without mention of alcoholism on the certificates. For the remaining 35 counties there were, in varying degrees, more certificates without mention of alcoholism than with mention of alcoholism.

The age-sex adjusted death rates for cirrhosis were computed and ranked for the 67 counties of the Commonwealth as of 1960 (table 10). In 10 counties the rates, ranging from 15 to 21 per 100,000 , were significantly greater than the State average; whereas in nine counties the rates, ranging from 3.6 to 2.3 per 100,000 , were significantly smaller than the State average. No deaths attributed to cirrhosis of the liver were reported in four small counties, Armstrong, Fulton, Juniata, and Wyoming.

\section{Discussion}

We found a strong association geographically between per capita sale of alcohol (implying consumption) and the death rate from cirrhosis for a given year. More detailed analyses of the data indicated, however, that this positive correlation by county was not ubiquitous but rather selective.

Table 9. Cirrhosis of liver death rate per 100,000 and association with per capita sale of alcohol according to percentage of county population in urban areas, Pennsylvania, 1960

\begin{tabular}{|c|c|c|c|}
\hline $\begin{array}{l}\text { Number of counties and } \\
\text { percent of population } \\
\text { in communities of } \\
2,500 \text { persons or more }\end{array}$ & $\begin{array}{l}\text { Adult } \\
\text { per } \\
\text { capita } \\
\text { alcohol } \\
\text { sales }\end{array}$ & 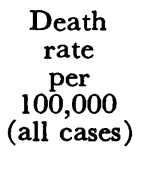 & $\begin{array}{l}\text { Association } \\
\text { with per } \\
\text { capita alco- } \\
\text { hol sale } \\
\text { (rank cor- } \\
\text { relation) }\end{array}$ \\
\hline $\begin{array}{l}15 \text { counties, less than } 25 \\
\text { percent_-- } \\
24 \text { counties, } 25 \text { to } 49 \\
\text { percent.-- } \\
26 \text { counties, } 50 \text { percent } \\
\text { or more.- } \\
24 \text { counties, } 50 \text { percent } \\
\text { or more, excluding } \\
\text { Allegheny and Phila- } \\
\text { delphia Counties.---- } \\
2 \text { counties, Allegheny } \\
\text { and Philadelphia, } 50 \\
\text { percent or more...-- }\end{array}$ & $\begin{array}{r}\$ 20.85 \\
28.73 \\
47.46\end{array}$ & $\begin{array}{r}5.9 \\
7.7 \\
13.3\end{array}$ & $\begin{array}{r}1+0.607 \\
+.097 \\
2+.538\end{array}$ \\
\hline
\end{tabular}

1 Statistically significant at least at the 5 percent level. 2 Statistically significant at least at the 1 percent level. Notz: Death rates were adjusted for age and sex. 
Specifically, the correlation was shown to exist only (a) in the socioeconomic grouping of counties classified as low according to the seven-factor composite index (population, housing, manufacturing, agriculture, mining, employment, and number of miles and size of highways), (b) in those counties with a median family income of more than $\$ 5,600$ or less than $\$ 4,800$ as of 1960 , and $(c)$ in those counties less than 25 percent urban or 50 percent or more urban as of 1960 .

Low socioeconomic status based on composite index and low family income would imply a low standard of living with an increased likelihood of dietary insufficiency, particularly a lack of lipotropic substances, and probably more frequent infections, both of which may synergistically interact with the toxic effect of alcohol in the pathogenesis of cirrhosis of the liver. The fact that the mortality rate from cirrhosis of the liver is greatest in the lowest socioeconomic class in Pennsylvania is consistent with the data for the United States pertaining to the occupational level (15), the Buffalo data regarding the four economic quarters (14), and with the results of the California study (19).

That the same correlation also exists in the high income areas suggests that, although the nutritional status of the population in such areas may be better, the average per capita consumption of alcohol was in fact much greater, and thus toxic effects of alcohol might play a more significant role in the etiology of this disease in such areas. Our data clearly indicated that there was a positive correlation between income and per capita consumption of alcohol. In England and Wales, as pointed out by Terris (15), mortality from cirrhosis of the liver is greatest in the upper classes when compared with the lower social classes where alcoholic beverages have been taxed out of reach.

The positive correlation between alcohol and cirrhosis found in the most urban counties might be attributed to a greater per capita consumption of alcohol, together with a probable dietary insufficiency, particularly among the poor in the metropolitan areas. In Philadelphia and Allegheny (which includes Pittsburgh) Counties, the average per capita consumption of alcohol _was as high as $\$ 61$; correspondingly the death rate from cirrhosis was as high as 15 per 100,000. The high correlation between alcohol and cirrhosis noted in the least urbanized areas, where the average amount of alcohol consumed was much less, might be related more significantly to the effects of dietary insufficiency, and probably other factors characteristic of the rural areas, such as less adequate medical care.

Table 10. Age and sex adjusted mortality rates attributed to cirrhosis of the liver and relative rank for counties, Pennsylvania, 1960

\begin{tabular}{|c|c|c|c|c|c|c|c|c|}
\hline County & $\begin{array}{l}\text { Adjusted } \\
\text { rate per } \\
100,000^{1}\end{array}$ & $\begin{array}{l}\text { Rank } \\
\text { order }\end{array}$ & County & $\begin{array}{l}\text { Adjusted } \\
\text { rate per } \\
100,000^{1}\end{array}$ & $\begin{array}{l}\text { Rank } \\
\text { order }\end{array}$ & County & $\begin{array}{l}\text { Adjusted } \\
\text { rate per } \\
100,000^{1}\end{array}$ & $\begin{array}{l}\text { Rank } \\
\text { order }\end{array}$ \\
\hline 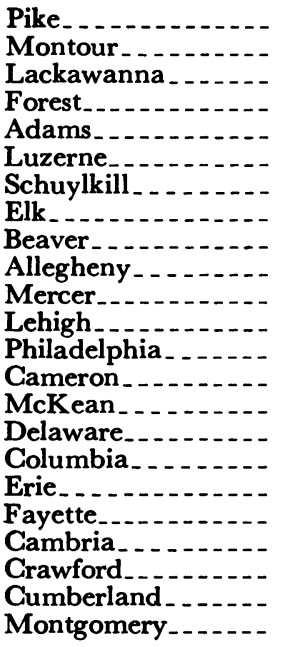 & $\begin{array}{l}21.1 \\
20.2 \\
18.8 \\
18.4 \\
18.3 \\
18.1 \\
18.1 \\
16.6 \\
15.5 \\
15.3 \\
14.5 \\
14.4 \\
14.1 \\
13.8 \\
12.5 \\
12.4 \\
12.1 \\
11.6 \\
11.6 \\
11.4 \\
11.4 \\
11.4 \\
11.2\end{array}$ & \begin{tabular}{r||}
1 \\
2 \\
3 \\
4 \\
5 \\
6 \\
6 \\
8 \\
9 \\
10 \\
11 \\
12 \\
13 \\
14 \\
15 \\
16 \\
17 \\
18 \\
18 \\
20 \\
20 \\
20 \\
23
\end{tabular} & $\begin{array}{l}\text { Sullivan } \\
\text { Washington } \\
\text { Northampton } \\
\text { Butler } \\
\text { Dauphin } \\
\text { Somerset } \\
\text { Mifflin } \\
\text { York } \\
\text { Monroe } \\
\text { Bucks } \\
\text { Carbon } \\
\text { Lycoming } \\
\text { Northumberland } \\
\text { Susquehanna } \\
\text { Westmoreland } \\
\text { Chester } \\
\text { Clearfield } \\
\text { Indiana } \\
\text { Lawrence } \\
\text { Venango. } \\
\text { Tioga } \\
\text { Centre. }\end{array}$ & $\begin{array}{r}11.1 \\
11.0 \\
10.8 \\
10.3 \\
9.9 \\
9.9 \\
9.2 \\
9.1 \\
9.0 \\
8.5 \\
8.2 \\
8.2 \\
8.0 \\
7.8 \\
7.7 \\
7.3 \\
7.2 \\
6.7 \\
6.5 \\
6.5 \\
6.3 \\
5.6\end{array}$ & $\begin{array}{l}24 \\
25 \\
26 \\
27 \\
28 \\
28 \\
30 \\
31 \\
32 \\
33 \\
34 \\
34 \\
36 \\
37 \\
38 \\
39 \\
40 \\
41 \\
42 \\
42 \\
44 \\
45\end{array}$ & $\begin{array}{l}\text { Warren } \\
\text { Huntingdon } \\
\text { Franklin } \\
\text { Lancaster } \\
\text { Greene } \\
\text { Blair } \\
\text { Union } \\
\text { Snyder } \\
\text { Bradford } \\
\text { Potter } \\
\text { Berks } \\
\text { Jefferson } \\
\text { Wayne } \\
\text { Perry } \\
\text { Clinton } \\
\text { Bedford. } \\
\text { Clarion } \\
\text { Lebanon } \\
\text { Armstrong } \\
\text { Fulton } \\
\text { Juniata } \\
\text { Wyoming }\end{array}$ & \begin{tabular}{l}
5.4 \\
5.2 \\
5.0 \\
4.9 \\
4.8 \\
4.6 \\
4.6 \\
4.3 \\
4.2 \\
4.2 \\
3.6 \\
3.5 \\
3.2 \\
3.0 \\
2.9 \\
2.4 \\
2.3 \\
2.3 \\
\hdashline.-- \\
\hdashline.-- \\
.--
\end{tabular} & $\begin{array}{l}46 \\
47 \\
48 \\
49 \\
50 \\
51 \\
51 \\
53 \\
54 \\
54 \\
56 \\
57 \\
58 \\
59 \\
60 \\
61 \\
62 \\
62 \\
64 \\
64 \\
64 \\
64\end{array}$ \\
\hline
\end{tabular}

1 Computed by the direct method of standardization (reference 17) using the 1960 Pennsylvania total population as standard. 
Interestingly, the death rate from cirrhosis was at least two times higher in the 50 percent or more urban areas (13 per 100,000$)$ as compared with that in areas with only less than 25 percent urban (six per 100,000). This difference clearly coincides with a similar difference in the average per capita consumption of alcohol. There was a clear and consistent three-way relationship between the degree of urbanization, the average alcohol consumption per capita, and the death rate from cirrhosis of the liver. Our analyses were based on the assumption that there is a close correlation between the amount of alcohol consumed and the sale value of alcohol for the same year. Available dollar sales data indicated that in Pennsylvania the ratio of "hard liquor" to wine was approximately 75 percent to 25 percent as of 1960 and that this ratio was relatively uniform for all counties.

It is difficult to explain why the rate of deaths from cirrhosis of the liver has increased consistently only among men and not among women in Pennsylvania. It might be that the frequency or the absolute amount of alcohol drinking, or both, have not increased substantially among women in recent years. It is unlikely that the nutritional status of women has improved more than that of men during the same period. It is not clear why the death rate from cirrhosis was higher among nonwhites than among whites in 1950 and in 1965, but the difference was reversed in 1955 and in 1960.

There were considerable geographic variations in the mortality rate from cirrhosis as well as in the practice of listing or not listing alcoholism on the death certificate. It is not known to what extent these variations, particularly the observed differences between urban and rural communities, are because of differences in the true incidence of the disease and of alcoholism or because of differences in diagnostic and reporting biases, or both. Detailed geographic studies are needed to determine the importance of the various toxic agents, organic or inorganic, that have been implicated in the etiology of cirrhosis.

\section{Conclusions}

The results of this study have revealed several important epidemiologic characteristics of cirrhosis of the liver. Perhaps the most important was the discovery that the mortality rate was directly related to the per capita consumption of alcohol, and that this positive relationship exists where certain other factors also prevail. Although these factors are related to socioeconomic status, family income, and urbanization, probably the most important underlying contributing factor is that of diet. The role of dietary insufficiency was not specifically evaluated in this study, however.

The level of cirrhosis mortality was much higher in the highest and the lowest income areas, in the most urban areas, and in the lowest socioeconomic index areas. In contrast, less consumption of alcohol plus relatively good nutritional standards for middle income families, lowest alcohol consumption for rural residents, and generally adequate diets and better medical care in high socioeconomic index areas might be responsible for the lower rates of mortality from cirrhosis in such segments of the population.

Another remarkable discovery was that the cirrhotic person at death was at least 10 years younger than would be expected; this shortened life expectancy was noted particularly among those with alcoholism in general and was especially evident among alcoholic women. This shortened life expectancy may be attributed, at least in part, to the fact that the alcoholic woman is less often identified for early treatment, and she is often more seriously addicted than is the alcoholic male.

Economic losses because of this disease in terms of both productivity and medical cost, together with the problem of alcoholism are apparent, and the importance of preventive measures is clearly indicated. If the dietary postulate as a significant contributing factor particularly in relation to alcohol consumption is correct, the development of an effective program of prevention and therapy for this liver disease could be within reasonable reach. The death rate for cirrhosis of the liver did not increase as much as that of the net increase in per capita consumption of alcohol. This fact, however, together with the complex relationships found between alcohol and cirrhosis, seems to indicate the presence of other etiologic factors. The data presented in our study also seem to imply certain threshold value and delayed (at least 5 years) effects of alcohol consumption on the cirrhosis mortality rate.

Unlike a popular conception, the relative importance of cirrhosis-as a cause of death in the presence of other competing risks of life-was highest in the 25-29 years age group. Although these deaths are apparently not associated with alcoholism, further studies are indicated to identify specific factors which would explain this discovery. 
(1) Mallory, F. B.: Cirrhosis of the liver. New Eng J Med 206: 1231-1239 (1932).

(2) Daft, F. S.: Experimental differentiation between liver necrosis and liver cirrhosis and some dietary factors affecting their development. Ann NY Acad Sci 57: 623-632 (1954).

(3) Connor, C. L.: Cirrhosis of the liver. Quart J Stud Alcohol 1: 95-103 (1940).

(4) Klatskin, G., Krehl, W. A., and Conn, H. O.: Effects of alcohol on choline requirement-I. Changes in rat's liver following prolonged ingestion of alcohol. J Exp Med 100: 605-614 (1954).

(5) Lieber, C. S., Spritz, N., and DeCarli, L. M.: Hepatic effects of ethanol given with deficient diet. Amer J Clin Nutr 18: 309 (1966).

(6) Rubin, E., and Lieber, C: Malnutrition and liver disease, an overemphasized relationship. Amer J Med 45: 1-6 (1968).

(7) Hartroft, W. S.: Alcohol metabolism and liver disease. Fed Proc 26: 1432-1435 (1967).

(8) Thomson, A, Baker, H., and Leevy, C. M.: Thiamine absorption in alcoholism. Amer $\mathrm{J}$ Clin Nutr 21: 537-538 (1968).

(9) Leevy, C. M., and Baker, H.: Nutritional deficiencies in liver disease. Med Clin N Amer 54: 467477 (1970).

(10) Gabuzda, G J., and Davidson, C. S.: Protein metabolism in patients with cirrhosis of the liver. Ann NY Acad Sci 57: 776-785 (1954).

(11) Mardones, J.: Metabolic and nutritional patterns in alcoholism. Ann NY Acad Sci 57: 788-793 (1954).

(12) Williams, R. J.: The genetrotrophic concept-nutritional deficiencies and alcoholism. Ann NY Acad Sci 57: 794-811 (1954).

(13) Joliffe, N., and Jellinek, E. M.: Cirrhosis of the liver. In Alcohol addiction and chronic alcoholism, edited by E. M. Jellinek. Yale University Press, New Haven, Conn., 1942.

(14) Lilienfeld, A. M., and Korn, R. F.: Some epidemiological aspects of cirrhosis of the liver: a study of mortality statistics. Amer J Hyg 52: 65-81 (1950).

(15) Terris, M.: Epidemiology of cirrhosis of the liver: national mortality data. Amer J Public Health 57: 2076-2088 (1967).

(16) U.S. Bureau of the Census: U.S. Census of Population: 1960. Vol. I, pt. 40, Characteristics of the population. Pennsylvania. U.S. Government Printing Office, Washington, D.C., 1963.

(17) Jaffe, A. J.: Handbook of statistical methods for demographers. Bureau of the Census, U.S. Government Printing Office, Washington, D.C., 1951.

(18) Miller, E. W.: An economic atlas of Pennsylvania Pennsylvania State University, State Planning Board, 1964.

(19) Pearl, A., Buechley, R., and Lipscomb, W.: Cirrhosis mortality in three large cities: implications for alcoholism and inter-city comparisons. In Society, culture, and drinking patterns, edited by D. Pittman and C. Snyder. John Wiley \& Sons, Inc., New York, 1962.

TOKUHATA, GEORGE K. (Pennsylvania Department of Health), DIGON, EDWARD, and RAMASWAMY, KRISHNAN: Alcohol sales and socioeconomic factors related to cirrhosis of the liver mortality in Pennsylvania. HSMHA Health Reports, Vol. 86, March 1971, pp. 253-264.

Because cirrhosis of the liver is often associated with a history of chronic alcoholism, the cirrhosis mortality data for Pennsylvania counties were analyzed historically and cross sectionally by consumption of alcohol and several socioeconomic and demographic characteristics. Death certificates filed in the State health department were reviewed, and the diagnosis given on the certificate was accepted. Data regarding sale of alcohol were taken from the State Liquor Control Board reports. Socioeconomic grouping of counties was derived from a special report of the State planning board. Other information was taken from the
U.S. census reports.

The mortality rate of cirrhosis was positively and significantly correlated with the per capita consumption of alcohol, particularly when certain socioeconomic characteristics also prevailed. The level of death from cirrhosis was higher in the highest and the lowest income areas, in the most urban areas, and in the lowest socioeconomic index areas. Life expectancy of patients with cirrhosis was at least 10 years shorter than would be expected; this shortened life expectancy was noted particularly among those with alcoholism and especially among alcoholic women.
The death rate from cirrhosis did not increase historically as much as that of the net increase in per capita consumption of alcohol. This fact, together with the complex relationship observed between cirrhosis and alcohol and between certain socioeconomic characteristics, seemed to indicate that other etiological factors, such as dietary insufficiency, were important. The relative importance of cirrhosis as a cause of death in the presence of other competing risks of life was highest in the age group 25-29 years. Further studies will have to be made before the different causes of cirrhosis of the liver are understood. 